\title{
CATCH RATE AND CATCH COMPOSITION OF FISH TRAWL BASED IN SIBOLGA, NORTH SUMATERA
}

\author{
Agustinus Anung Widodo ${ }^{1)}$ and Mahiswara ${ }^{2)}$ \\ 1) Researcher at Research Center for Fisheries Management and Conservation, Ancol-Jakarta \\ 2) Researcher at Research Institute for Marine Fisheries, Muara Baru-Jakarta \\ Received January 28-2011; Received in revised form June 23-2011; Accepted July 12-2011
}

\begin{abstract}
To obtain data and information of fish trawl fishery performance operated in the Indian Ocean, a research was carried out through observation on board by observers as well as port sampling in Sibolga Fishing Port by enumerators in September 2007, with the aimed to study the performance fish trawl fishery. These include fleet structure, trawl net design and construction, catch, fishing trip, fishing ground, and fishing operation. Results of research showed that there were 71 registered fish trawlers in Sibolga Fishing Port and only 25 boats active due to increasing of fuel price. The fleet structure of fish trawler consist of boat with size 31-114 GT which can be classified into 3 categories i.e. small (<60 GT), medium (60-150 GT), and large fish trawler (>150 GT). Design and construction of fish trawl net indicated that fish trawl net operates in the Indian Ocean was high opening trawl with head and ground rope of 27.8-41.5 $\mathrm{m}$ and 29,7-45.8 m, respectively. Fishing trip generally 10-12 days with effective days 7-9 days per trip and the number of net setting was 5-6 times each day. The fishing grounds of fish trawl based in Sibolga were the coastal waters area with maximum depth of $91 \mathrm{~m}$. At least 40 species of fishes and shrimps identified during research and dominant fish species was ponyfish (Leiognathus spp.) threadfin bream (Nemipterus spp.), tall fin goatfish (Upeneus spp.), sea catfish (Arius sp.) as well as yellow striped goatfish (Upeneus vitattus). The average of catch of fish trawler fleet in the year of 2007 was $249.3 \mathrm{~kg} / \mathrm{haul}$ and that number seems smaller than average of catch/haul previous years. This situation indicates that decreasing of catch per haul of fish trawlers based in Sibolga continues occurring and in other hand price of fuel raises significantly so that big fish trawlers size 150 GT with engine power more than $600 \mathrm{HP}$ are not able to continue their fishing operation.
\end{abstract}

KEYWORDS: $\quad$ fish trawl, fishery, Sibolga

\section{INTRODUCTION}

Fish trawl was one of very productive fishing gear operates in Indonesian Exclusive Economic Zone including Indian Ocean. The operation of fish trawl has been regulated through Decree of Ministry of Agriculture 770/Kpts./IK.120/10/1996 on the Use of fishnet in the Indonesian Exclusive Economic Zone of West Sumatera and Aceh waters and being updated by Minister of Marine Affairs and Fisheries Regulation Nomor: 11/Men/2009 on the use of fishnet in the Indonesian Exclusive Economic Zone. Trawlers fishing allowed operating in the Indonesian Exclusive Economic Zone waters of the Indian Ocean especially west of Sumatera, the waters around Aceh Province in the coordinates of $4^{\circ} \mathrm{N}-96^{\circ} \mathrm{E}$.

According to the Decree of the Minister of Agriculture 770/Kpts./IK.120/10/1996 and Minister of Marine Affairs and Fisheries Regulation Nomor: 11/ Men./2009, fish trawl was allocated to fish in the mid waters layer (bathy pelagic). The Ministerial Regulation also defined that fish trawl as fishing nets equipped with a pair of otter board to open the net mouth. Widodo (2008) indicated that fish trawl classified into the group of bottom trawl net because the technical character is exactly similar with bottom trawls.

Decreasing of catch year by year is a serious issue facing by fish trawling fleet in Sibolga currently. According to Muharam (2006) that catch average of fish trawlers in the year of 2005 was $357 \mathrm{~kg} / \mathrm{haul}$ and in 2006 was $287 \mathrm{~kg} / \mathrm{haul}$. In other hand the price of fuel is increasing significantly so that large fish trawler with engine power $>600 \mathrm{HP}$ has no longer to operate. The research is aimed to study of some aspects of the fish trawl fishery including fleet structure, design and construction of fish trawl, fishing operation, and fish catch.

\section{MATERIALS AND METHODS}

The primary data consist of fleet structure, trawl design and construction, fishing strategy, and the catch is collected in September 2007. Fleet structures data obtained from Sibolga Nusantara Fishing Port whilst design and construction of fish trawl net obtained through an observation and measurement of some boats sample which is taken randomly. Fishing 
strategy data includes fishing ground, fishing time, net towing duration, and the number of catch per haul were collected through onboard observation by three trained observers in the three fish trawlers. Three fish trawlers were randomly selected i.e. KM. Alam Jaya (55 GT), KM. Harapan Makmur (83 GT), and KM. Istana Samudera Indonesia (114 GT). Species composition and size of catch obtained through sampling of fish trawlers unloading in the private fishing port called as tangkahan. Sampling activities are carried out by three enumerators.

Sampling activities is proceed when the vessels unloading their catch. The sample taken from each vessel was 3 baskets which the volume of each basket was around 40-50 kg. Moreover, samples are sorted by species. The species identification is referred to Compagno (1999); Cressey \& Waples (1984); Sainsbury, Kailola, \& Leyland (1985); Sommer, Schneider, \& Poutiers (1996). Finally, data analyzed by using descriptive method and presented as tables and graphics.

\section{RESULTS AND DISCUSSION}

\section{Result}

\section{a. Fleet}

The fish trawl fleet based in Sibolga was wooden boat with the size 31-130 GT and powered by diesel engine 280-1,200 HP. The number of registered fish trawler in Sibolga Nusantara Fishing Port is 71 boats and the active boat about 25 fleet, structure showed in Table 1 (Appendix 1) and Figure 1. Result of analysis showed that the active of fish trawlers fleet dominated by boats of 51-100 GT with engine power of 350-600 HP.

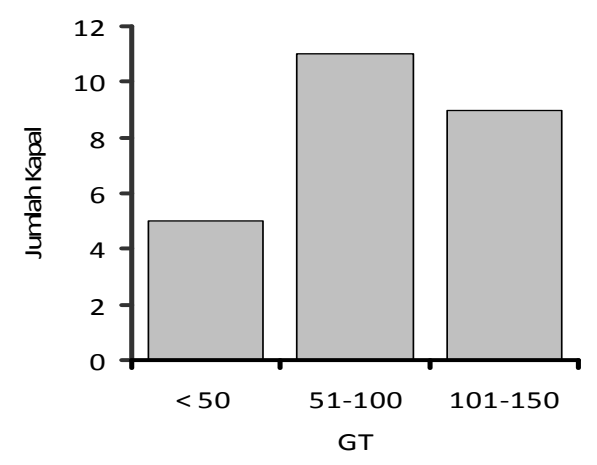

Figure 1. Fleet structure of active fish trawler operating in Indian Ocean year of 2007.

\section{b. Fishing Gear}

It has been explained that fish trawl actually the bottom trawl targeting the demersal fish. The main part (section) of fish trawl net consists of wing net, body net, and codend. Design and construction of fish trawl net is obtained from observation and measurement to a sample of KM. Alam Jaya (55 GT). The result of observation showed that fish trawl net has a head rope $30.0 \mathrm{~m}$ and ground rope $33.0 \mathrm{~m}$. Mesh size of wing net around $240-480 \mathrm{~mm}$, body of net around 30-180 mm and codend was $20 \mathrm{~mm}$. Net materials was polyamide with yarn diameter varies for each part (section). Yarn diameter on wing part is 3-4 $\mathrm{mm}$, body part 2-3 $\mathrm{mm}$, and codend $2 \mathrm{~mm}$ (Figure 2). Fish trawl equipped with a pair of otter boat sized $170 \times 120 \mathrm{~cm}$. Along the head rope attached 62 reinforced plastic floats diameter $20 \mathrm{~cm}$ and 196 cylindrical rubber bobbin combined wit steel chain diameter $13 \mathrm{~mm}$ along ground rope as sinker. The size of each bobbin was $12 \mathrm{~cm}$ in diameter and 18 $\mathrm{cm}$ in length. Results of head and ground rope measurement of the fish trawl nets were 27.8-41.5 m and 29,7-45.8 m, respectively (Table 2 on Appendix 2).

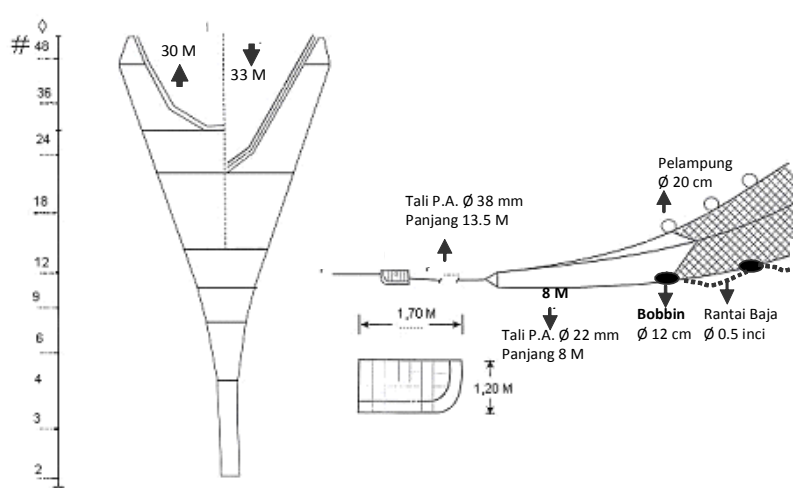

Figure 2.

The design and construction of fish trawl net of KM. Alam Jaya (55 GT).

\section{c. Fishing Operation}

The number of crew of fish trawlers were generally 10-12 people whilest fishing trips were 10-12 days with 7-9 effective days and number of net setting was 5-6 times a day. The net setting was only occurred on the day i.e. during 4:00 am to 06:00 pm. During the night time, fish trawl do not operate to avoid conflict with purse seine fishers who engage fishing operations in the same fishing ground. Towing speed average was around 2-2.5 knots with average of towing duration was 2.04 hours. Catch usually preserved with ice, but there were some fish trawler equipped refrigeration machine that serve to maintain the ice not to melt. In 
general, fishing ground is the coastal area between 30-100 m depth. The observers reported that there were 4 locations of fishing ground of 3 fish trawlers i.e. KM. Alam Jaya (55 GT), KM. Tunas Harapan (83 GT), and KM. Istana Samudera Indonesia (114 GT) as shown in Figure 3. Based on Figure 3 it can be explained that KM. Alam Jaya operates in the coastal around of Sinabang Islands (FG-1) and along of coastal between Sibolga and Meulaboh (FG-2). KM. Tunas Harapan operates in the coastal west of Sinabang Islands (FG-4), while the KM. Istana Samudera Indonesia operates in the fishing ground coded FG-3 or coastal of Meulaboh. The fishing grounds of fish trawl based in Sibolga were a coastal waters area with maximum depth of $91 \mathrm{~m}$.

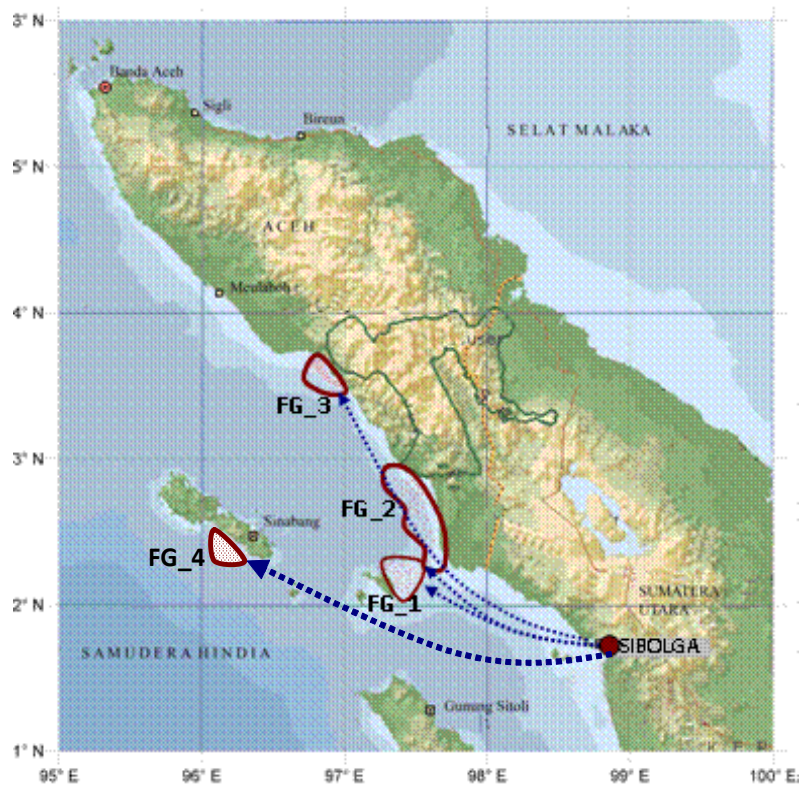

Figure 3. Fishing grounds of KM. Alam Jaya, KM. Tunas Harapan, and KM. Istana Samudera Indonesia in September 2007.

\section{d. Catch}

\section{Catch per hauling}

Result of onboard observation showed that average of catch of MV. Alam Jaya from the fishing ground FG-1 and FG-2 were $206.46 \mathrm{~kg} / \mathrm{haul}, \mathrm{MV}$. Tunas Harapan in the F.G-4 was $240.4 \mathrm{~kg} / \mathrm{haul}$ and MV. Istana Samudera Indonesia was $301.10 \mathrm{~kg} / \mathrm{haul}$ (Appendix 3, 4, and 5). The average of catch of each fish trawler in the year of 2007 was 206.5, 240.4, and $301.1 \mathrm{~kg} / \mathrm{haul}$ or $249.3 \mathrm{~kg} / \mathrm{haul}$ in average (Tabel 1).

As mentioned previously that the catch rate average of fish trawls 2005 and 2006 were 357, kg/ haul $287 \mathrm{~kg} / \mathrm{haul}$ respectively. Seeing the results of research in 2007 , so that the of fish trawl catch rate average is steadily declining.

\section{Species composition}

Identification of sample caught by KM. Tunas Harapan and KM. Istana Samudera Indonesia indicate that at least there were 36 species of fish and 4 shrimp caught in the Indian Ocean (Table 2). From the 36 species, splendid pony fish (Leiognathus spenden) was the highest percentage i.e. $10.81 \%$ of total catch. Other species in large number were threadfin bream (Nemipterus japonicus) 9.82\%, tall fin goatfish (Upeneus indicus) 8.32\%, spotted catfish (Arius maculatus) $6.81 \%$, as well as yellow striped goatfish (Upeneus vitattus) 6.76\%. However, the highest percentage of the catch i.e. $12.3 \%$ was trash fish or by local fishers called as ikan pasifik. This thrash fish usually used as a raw material of fish meal. 
Table 1.

Catch per haul of fish trawler in the year of 2007

\begin{tabular}{|c|c|c|c|c|}
\hline \multirow[b]{2}{*}{ Parameters } & \multicolumn{3}{|c|}{ Fish trawler } & \multirow[b]{2}{*}{ Average } \\
\hline & MV. Alam Jaya & MV. Tunas Harapan & $\begin{array}{c}\text { MV. Istana } \\
\text { S.Indonesia }\end{array}$ & \\
\hline Number of haul & 29 & 26 & 22 & 25.7 \\
\hline Minimum catch/haul $(\mathrm{kg})$ & 177 & 151.7 & 200.4 & 176.4 \\
\hline Maximum catch/haul (kg/haul) & 251.5 & 371.5 & 470 & 364.3 \\
\hline Average catch $(\mathrm{kg})$ & 206.5 & 240.4 & 301.1 & 249.3 \\
\hline Standard deviation & 18 & 52.1 & 66.7 & 45.6 \\
\hline Coefficient of variant (CV) & 8.7 & 21.7 & 22.1 & 17.5 \\
\hline
\end{tabular}

Table 2.

Species composition and the percentage of catch of fish trawl base in Sibolga in the year of 2007

\begin{tabular}{|c|c|c|c|c|c|c|c|}
\hline \multirow[b]{2}{*}{ No. } & \multirow[b]{2}{*}{ English name } & \multirow[b]{2}{*}{ Indonesian name } & \multirow[b]{2}{*}{ Scientific name } & \multicolumn{4}{|c|}{ Species compsition } \\
\hline & & & & $\begin{array}{c}\text { Catch of } \\
\text { MV. ISI } \\
(\mathrm{kg})\end{array}$ & $\begin{array}{l}\text { Catch } \\
\text { of } \\
\text { MV. TH } \\
\text { (kg) }\end{array}$ & $\begin{array}{c}\text { Total } \\
(\mathbf{k g})\end{array}$ & $\%$ \\
\hline I. & Fish & Ikan & & & & & \\
\hline 1. & Strawberry grouper & Kerapu merah & Cephalopholis analis & 48 & 12 & 60 & 0.31 \\
\hline 2. & Threadfin bream & Kurisi & Nemipterus japonicus & 850 & 1,040 & 1,890 & 9.82 \\
\hline 3. & Red snapper & Kakap merah & Lutjanus sp. & 360 & 60 & 420 & 2.18 \\
\hline 4. & Spotted catfish & Manyung & Arius maculatus & 820 & 490 & 1,310 & 6.81 \\
\hline 5. & Giant cat fish & Manyung & Arius thalassinus & 340 & 270 & 610 & 3.17 \\
\hline 6. & Great barracuda & Alu-alu & Sphyraena barracuda & 500 & 430 & 930 & 4.83 \\
\hline 7. & Pickhandle barracuda & Alu-alu & Sphyraena jello (Cuvier,1829) & 320 & 210 & 530 & 2.75 \\
\hline 8. & Chub mackerel & Banyar & Rastrelliger kanagurta & 400 & 140 & 540 & 2.81 \\
\hline 9. & Spendid ponyfish & Petek & Leiognathus splenden & 1,100 & 980 & 2,080 & 10.81 \\
\hline 10. & Razor trevally & Eteman & Mene maculata & 80 & 0 & 80 & 0.42 \\
\hline 11. & Emperor & Lencam & Lethrinus elongata & 31 & 20 & 51 & 0.27 \\
\hline 12. & Tall-fin goatfish & Kuniran & Upeneus indicus & 870 & 730 & 1,600 & 8.32 \\
\hline 13. & Hairtail & Layur & Trichiurus spp. & 218 & 120 & 338 & 1.76 \\
\hline 14. & Golden rabbit fish & Baronang & Siganus guttatus & 70 & 37 & 107 & 0.56 \\
\hline 15. & Pearly spinefoot & Baronang & Siganus canaliculatus & 125 & 20 & 145 & 0.75 \\
\hline 16. & Batfish & Kambing-kambing & Aluterus sp. & 55 & 15 & 70 & 0.36 \\
\hline 17. & Big eye & Swanggi & Priacanthus spp. & 168 & 80 & 248 & 1.29 \\
\hline 18. & Bluefin trevally & Kue & Caranx melampygus & 45 & 22 & 67 & 0.35 \\
\hline 19. & Silver grunt & Tigawaja & Pomadasys sp. & 130 & 230 & 360 & 1.87 \\
\hline 20. & Hammer head shark & Cucut martil & Sphyrna lewini & 35 & 82 & 117 & 0.61 \\
\hline 21. & Silky shark & Cucut layaman & Charcarinus falciformis & 71 & 0 & 71 & 0.37 \\
\hline 22. & Big jawed jumber & Kapasan & Lactarius lactarius & 640 & 300 & 940 & 4.89 \\
\hline 23. & Greater lizard fish & Bloso & Saurida tumbil & 470 & 260 & 730 & 3.79 \\
\hline 24. & Indopacific mackerel & Kembung & Rastrelliger brachysoma & 600 & 155 & 755 & 3.92 \\
\hline 25. & Largescaled terapon & Kerong-kerong & Terapon theraps & 460 & 290 & 750 & 3.90 \\
\hline 26. & Yellow striped goatfish & Bijinangka & Upeneus vitatus & 790 & 510 & 1,300 & 6.76 \\
\hline 27. & Redbelly yellowtail fusilier & Ekor kuning & Caesio cuning (Bloch,1791) & 270 & 190 & 460 & 2.39 \\
\hline 28. & White ppmfret & Bawal & Pampus argenteus & 15 & 24 & 39 & 0.20 \\
\hline 29. & Black pomfret & Bawal hitam & Formio niger & 26 & 11 & 37 & 0.19 \\
\hline 30. & Mullet & Belanak & Mugil cephalus & 3 & 0 & 3 & 0.02 \\
\hline 31. & Blotched javelin fish & Gerot-gerot & Pomadasys maculatus & 49 & 38 & 87 & 0.45 \\
\hline 32. & Indian spiny turbot & Ikan sebelah & Psettodes erumi & 23 & 0 & 23 & 0.12 \\
\hline 33. & Flatfish/halibut & Ikan lidah & Pseudorombus spp. & 16 & 0 & 16 & 0.08 \\
\hline 34. & Solefish & Ikan lidah & Cynoglossus spp. & 12 & 0 & 12 & 0.06 \\
\hline 35. & Spotted sicklefish & Ketang-ketang & Drepane spp. & 68 & 15 & 83 & 0.43 \\
\hline 36. & $\begin{array}{l}\text { Grouper } \\
\text { Shrimp }\end{array}$ & $\begin{array}{l}\text { Kerapu sunu } \\
\text { Udang }\end{array}$ & Ephinepelus sp. & 0 & 23 & 23 & 0.12 \\
\hline 1. & Tiger prawn & Udang windu & Penaeus semisulcatus & 8 & 0 & 8 & 0.04 \\
\hline 2. & Banana shrimp & Udang putih & Penaeus indicus & 13 & 4 & 17 & 0.09 \\
\hline 3. & Flathead lobster & Udang kipas & Thenus orientalis & 7 & 2 & 9 & 0.05 \\
\hline 4. & Endeavour shrimp & Udang krosok & Metapenaeus endeavouri & 16 & 6 & 22 & 0.11 \\
\hline III. & Other & Lainnya & & & & & \\
\hline \multirow[t]{2}{*}{1.} & Trash fish & Ikan rucah & Thrashfish & 1,400 & 900 & 2,300 & 11.96 \\
\hline & Total & & & 11,522 & 7,716 & 19,238 & 100 \\
\hline
\end{tabular}




\section{DISCUSSION}

Result of this research showed that fish trawl fleet structure is began from smallest to the biggest i.e. 31-144 GT. Based on the range of gross tonnage, the fish trawl gears can be grouped into 3 categorizes i.e. small (<60 GT), medium (60-150 GT), and large (>150 GT). In this case the small vessel represented by KM. Alam Jaya (55 GT), medium vessel represented by KM. Tunas Harapan (83 GT) and KM. Istana Samudera Indonesia (114 GT). None large category fish trawler represented to be observed in the research because there is no large fish trawler is still active.

Large fish trawler with engine power $>600 \mathrm{HP}$ has no longer operates since the increase of fuel price. The fishing industry is highly dependent on the fuel energy propulsion of the fishing boats and operation of the fishing gear, the recent situation in the high price of fuel price has created problem to fisheries both in developed and developing countries including Indonesia because the increased operation cost usually do not follow by increased fish price.

Fuel consumption of fish trawlers with the engine power d"600 HP is relatively low. The estimation of fuel consumption of boat with engine $600 \mathrm{HP}$ was 110-130 L/hour (Personal Communication with Chief Engine of KM. Harapan Makmur, 2007). The average of fuel consumption of KM. Harapan Makmur is 117 L/hour. He informed also that the total cost for purchasing of fuel reach $65-68 \%$ of the total fishing operations cost. From the aspect of a fishing business, fish trawler powered by engine less than d"600 HP is still profitable.

Fish trawl designed in such a way to have a high vertical mouth opening (high opening mouth). This design eventually impacted to the small pelagic fish caught. The results of this research noted that the number of small pelagic fish caught was $17.7 \%$. As a result, it creates a confusion to many people deemed that fish trawl is mid water trawl but actually bottom trawl. The size of head rope is 5-10\% shorter than the length of its ground rope, whereas one of characteristic of mid water trawl is the size of head rope must longer than its ground rope.

The differences of catch between the three fish trawlers i.e. KM. Alam Jaya, KM. Tunas Harapan, and KM. Istana Samudera Indonesia were 206.46, 240.4 , and $301.10 \mathrm{~kg} / \mathrm{haul}$, respectively due to different of fishing ground, lengths of head rope, and duration of towing time. However, the stock abundance of fish in each of fishing ground mentioned above still unknown. If the abundance of fish stock in each fishing ground can be assumed equally, then the differences in length of head rope is an important factor of differences in catch per haul of each fish trawler. Results of previous studies showed that the average catch per haul fish trawlers in 2005 was $357.1 \mathrm{~kg} /$ haul and in 2006 was $286.9 \mathrm{~kg} / \mathrm{haul}$ (Muharam, 2006). The average of catch per haul of three fish trawlers above is $249.3 \mathrm{~kg} / \mathrm{haul}$. This result of research indicates that the decline in fish catch trawling still occurs.

\section{CONCLUSION}

The fishing industry including fish trawl is highly dependent on the fuel energy, large fish trawler with engine power $>600 \mathrm{HP}$ in Sibolga has no longer operates since the increase of fuel price. The average of catch of fish trawler fleet in the year of 2007 is $249.3 \mathrm{~kg} / \mathrm{haul}$ and that number seems smaller than average of catch/haul previous years. At least 40 species of fishes and shrimps identified during research and dominant fish species is ponyfish (Leiognathus spenden) threadfin bream (Nemipterus japonicus), tall fin goatfish (Upeneus indicus), sea catfish (Arius sp.) as well as yellow striped goatfish (Upeneus vitattus).

\section{ACKNOWLEDGMENTS}

This paper is part of the research result of the TEDs and JTEDs for fish trawl in the EEZ Indian Ocean in 2006-2007, financed by the GEF and FAO. We would like to thanks to Mr. Henry Batubara (Head of Sibolga Fishing Port) and Mr. Agus Situmorang (Coordinator of observer and enumerator program in Sibolga Fishing Port) for their significant contributions especially fleet data providing.

\section{REFERNCES}

Cressey, R. F. \& R. S. Waples. 1984. Synodontidae. In W. Fischer \& G. Bianchi (eds.) Food and Agriculture Organization Species Identification Sheets for Fishery Purposes. Western Indian Ocean (Fishing Area 51). Volume 4. Food and Agriculture Organization. Rome.

Compagno, L. J. V. 1999. The Living Marine Resource of the Western Central Pacific. Food and Agriculture Organization. Rome. 3: 1,398-1,529.

Muharam, D. 2006. Studi kelayakan usaha pukat ikan dilihat dari aspek teknis dan aspek finansial pada KM. Harapan Makmur, Sibolga. Karya IImiah Praktek Akhir. Sekolah Tinggi Perikanan. Jakarta (Unpublished). 
Sainsbury, K. J., P. J. Kailola, \& G. G. Leyland. 1985. Continental Shelf Fishes of Nothern and North Western Australia. CSIRO Division of Fisheries Research-Canbera-Autralia. 375 pp.

Sommer, C., W. Schneider, \& J. M. Poutiers. 1996. Food and Agriculture Organization species identification field guide for fishery purposes. The Living Marine Resources of Somalia. Food and Agriculture Organization. Rome. 376 pp.
Widodo, A. A. 2008. Teknologi trawl yang beroperasi di Laut Arafura dan sekitarnya. Sumber Daya, Pemanfaatan, dan Opsi Pengelolaan Perikanan di Laut Arafura. BIODINEX 2 Laut Arafura (Buku Bunga Rampai). Balai Riset Perikanan Laut. Pusat Riset Perikanan Tangkap. Badan Riset Kelautan dan Perikanan. 21-33. 
Appendix Table 1. The list of active fish trawlers based in Sibolga operating in Indian Ocean in the year of 2007

\begin{tabular}{|c|c|c|c|}
\hline No. & Boat name & Gross tonnage (GT) & Engine power (HP) \\
\hline 1. & KM. Agung Samudera Nauli & 111 & 700 \\
\hline 2. & KM. Elina & 40 & 370 \\
\hline 3. & KM. Harapan Makmur & 83 & 600 \\
\hline 4. & KM. Harapan Makmur I & 80 & 600 \\
\hline 5. & KM. Hasil Karya Sukses I & 101 & 600 \\
\hline 6. & KM. Hasil Karya Sukses II & 103 & 600 \\
\hline 7. & KM. Hasil Karya Sukses III & 104 & 600 \\
\hline 8. & KM. Hasil Karya Sukses Indah I & 100 & 600 \\
\hline 9. & KM. Hasil Karya Sukses Indah II & 103 & 600 \\
\hline 10. & KM. Jala Jaya I & 120 & 600 \\
\hline 11. & KM. Jimmy 02 & 35 & 350 \\
\hline 12. & KM. Jimmy 03 & 60 & 350 \\
\hline 13. & KM. Karya Budi Nelayan VI & 31 & 350 \\
\hline 14. & KM. Naga Mas Baru & 85 & 350 \\
\hline 15. & KM. Nusantara & 69 & 350 \\
\hline 16. & KM. Samudera Era Mas Abadi XII & 35 & 280 \\
\hline 17. & KM. Sumber Cipta & 128 & 600 \\
\hline 18. & KM. Sumber Maju & 90 & 350 \\
\hline 19. & KM. Sumber Rezeki Bersama 03 & 37 & 350 \\
\hline 20. & KM. Tapian Nauli & 70 & 300 \\
\hline 21. & KM. Tunas Rezeki & 74 & 350 \\
\hline 22. & KM. Tunas Harapan & 83 & 700 \\
\hline 23. & KM. Alam Jaya & 55 & 350 \\
\hline 24. & KM. Istana Samudera Indonesia & 114 & 600 \\
\hline 25. & KM. Angkasa Surya Agung & 90 & 350 \\
\hline \multicolumn{2}{|c|}{ Average } & 80.04 & 474.0 \\
\hline \multicolumn{2}{|c|}{ Standard deviation (SD) } & 28.81 & 143.4 \\
\hline \multicolumn{2}{|c|}{ Coefficient of variance (CV) } & $36 \%$ & $30 \%$ \\
\hline
\end{tabular}


Appendix Table 2. Length of head and ground ropes of 25 active fish trawl nets vessel operating in Indian Ocean and base in Sibolga in the year of 2007

\begin{tabular}{|c|c|c|c|c|}
\hline \multirow{2}{*}{ No. } & \multirow{2}{*}{ Boat name } & \multirow{2}{*}{ Gross tonnage (GT) } & \multicolumn{2}{|c|}{ Lenght of ropes $(\mathrm{m})$} \\
\hline & & & Head rope & Ground rope \\
\hline 1. & KM. Agung Samudera Nauli & 111 & 39.6 & 42.5 \\
\hline 2. & KM. Elina & 40 & 27.8 & 29.7 \\
\hline 3. & KM. Harapan Makmur & 83 & 34.4 & 36.5 \\
\hline 4. & KM. Harapan Makmur I & 80 & 37.1 & 39.4 \\
\hline 5. & KM. Hasil Karya Sukses I & 101 & 39.2 & 42.3 \\
\hline 6. & KM. Hasil Karya Sukses II & 103 & 39.9 & 43.1 \\
\hline 7. & KM. Hasil Karya Sukses III & 104 & 38.0 & 40.2 \\
\hline 8. & KM. Hasil Karya Sukses Indah I & 100 & 37.6 & 39.7 \\
\hline 9. & KM. Hasil Karya Sukses Indah II & 103 & 38.1 & 41.6 \\
\hline 10. & KM. Jala Jaya I & 120 & 40.0 & 42.9 \\
\hline 11. & KM. Jimmy 02 & 35 & 31.8 & 33.9 \\
\hline 12. & KM. Jimmy 03 & 60 & 32.1 & 34.2 \\
\hline 13. & KM. Karya Budi Nelayan VI & 31 & 26.2 & 28.3 \\
\hline 14. & KM. Naga Mas Baru & 85 & 36.1 & 38.3 \\
\hline 15. & KM. Nusantara & 69 & 33.2 & 35.4 \\
\hline 16. & KM. Samudera Era Mas Abadi XII & 35 & 32.4 & 34.7 \\
\hline 17. & KM. Sumber Cipta & 128 & 41.5 & 44.8 \\
\hline 18. & KM. Sumber Maju & 90 & 37.0 & 39.1 \\
\hline 19. & KM. Sumber Rezeki Bersama 03 & 37 & 32.8 & 34.2 \\
\hline 20. & KM. Tapian Nauli & 70 & 34.1 & 36.6 \\
\hline 21. & KM. Tunas Rezeki & 74 & 34.7 & 36.9 \\
\hline 22. & KM. Tunas Harapan & 83 & 35.2 & 37.6 \\
\hline 23. & KM. Alam Jaya & 55 & 30.4 & 33.0 \\
\hline 24. & KM. Istana Samudera Indonesia & 114 & 40.0 & 42.9 \\
\hline 25. & KM. Angkasa Surya Agung & 90 & 38.1 & 40.3 \\
\hline \multicolumn{2}{|c|}{ Average } & 80.04 & 35.65 & 37.79 \\
\hline \multirow{2}{*}{\multicolumn{2}{|c|}{$\begin{array}{l}\text { Standard deviation (SD) } \\
\text { Coefficient of variance (CV) }\end{array}$}} & 28.81 & 4.25 & 4.47 \\
\hline & & $36 \%$ & $12 \%$ & $12 \%$ \\
\hline
\end{tabular}


Appendix Table 3. Catch of KM. Alam Jaya in the fishing ground FG-1 and FG-2 in September 2007

\begin{tabular}{|c|c|c|c|c|c|}
\hline $\begin{array}{c}\text { No. } \\
\text { Setting }\end{array}$ & $\begin{array}{l}\text { Position } \\
\text { (Lat-Lon) }\end{array}$ & $\begin{array}{c}\text { Depth range } \\
(\mathrm{m})\end{array}$ & $\begin{array}{l}\text { Towing duration } \\
\text { (minute) }\end{array}$ & $\begin{array}{c}\begin{array}{c}\text { Towing speed } \\
\text { (knot) }\end{array} \\
\end{array}$ & $\begin{array}{c}\text { Catch } \\
(\mathrm{kg})\end{array}$ \\
\hline 1 & $2^{\circ} 05^{\prime} \mathrm{N}-97^{\circ} 25^{\prime} \mathrm{E}$ & $43-61$ & 101 & 2.8 & 209.0 \\
\hline 2 & $2^{\circ} 06^{\prime} \mathrm{N}-97^{\circ} 28^{\prime} \mathrm{E}$ & $66-68$ & 120 & 3.0 & 223.0 \\
\hline 3 & $2^{\circ} 08^{\prime} N-97^{\circ} 26^{\prime} E$ & $32-54$ & 115 & 2.9 & 194.0 \\
\hline 4 & $2^{\circ} 11^{\prime} N-97^{\circ} 24^{\prime} E$ & $41-62$ & 120 & 3.0 & 199.9 \\
\hline 5 & $2^{\circ} 12^{\prime} \mathrm{N}-97^{\circ} 24^{\prime} \mathrm{E}$ & $43-48$ & 120 & 3.1 & 187.8 \\
\hline 6 & $2^{\circ} 10^{\prime} \mathrm{N}-97^{\circ} 29^{\prime} \mathrm{E}$ & $36-44$ & 130 & 3.0 & 183.0 \\
\hline 7 & $2^{\circ} 13^{\prime} \mathrm{N}-97^{\circ} 28^{\prime} \mathrm{E}$ & $51-53$ & 110 & 2.9 & 208.7 \\
\hline 8 & $2^{\circ} 13^{\prime} \mathrm{N}-97^{\circ} 27^{\prime} \mathrm{E}$ & $66-68$ & 120 & 3.1 & 178.0 \\
\hline 9 & $2^{\circ} 12^{\prime} \mathrm{N}-97^{\circ} 21^{\prime} \mathrm{E}$ & $42-47$ & 120 & 3.0 & 197.0 \\
\hline 10 & $2^{\circ} 10^{\prime} \mathrm{N}-97^{\circ} 24^{\prime} \mathrm{E}$ & $38-41$ & 130 & 2.9 & 251.5 \\
\hline 11 & $2^{\circ} 11^{\prime} \mathrm{N}-97^{\circ} 21^{\prime} \mathrm{E}$ & $55-57$ & 120 & 3.0 & 204.7 \\
\hline 12 & $2^{\circ} 13^{\prime} \mathrm{N}-97^{\circ} 20^{\prime} \mathrm{E}$ & $51-54$ & 130 & 3.0 & 233.8 \\
\hline 13 & $2^{\circ} 15^{\prime} \mathrm{N}-97^{\circ} 19^{\prime} \mathrm{E}$ & $62-67$ & 120 & 3.1 & 194.0 \\
\hline 14 & $2^{\circ} 14^{\prime} N-97^{\circ} 18^{\prime} E$ & $39-44$ & 120 & 3.0 & 210.7 \\
\hline 15 & $2^{\circ} 16^{\prime} \mathrm{N}-97^{\circ} 14^{\prime} \mathrm{E}$ & $30-33$ & 110 & 3.0 & 206.8 \\
\hline 16 & $2^{\circ} 19^{\prime} \mathrm{N}-97^{\circ} 15^{\prime} \mathrm{E}$ & $62-69$ & 130 & 3.0 & 204.0 \\
\hline 17 & $2^{\circ} 17^{\prime} \mathrm{N}-97^{\circ} 18^{\prime} \mathrm{E}$ & $64-68$ & 130 & 3.1 & 197.6 \\
\hline 18 & $2^{\circ} 21^{\prime} \mathrm{N}-97^{\circ} 19^{\prime} \mathrm{E}$ & $46-51$ & 120 & 2.9 & 201.3 \\
\hline 19 & $2^{\circ} 18^{\prime} \mathrm{N}-97^{\circ} 21^{\prime} \mathrm{E}$ & $33-38$ & 130 & 3.0 & 202.0 \\
\hline 20 & $2^{\circ} 19^{\prime} \mathrm{N}-97^{\circ} 22^{\prime} \mathrm{E}$ & $45-48$ & 130 & 2.9 & 232.0 \\
\hline 21 & $2^{\circ} 19^{\prime} \mathrm{N}-97^{\circ} 22^{\prime} \mathrm{E}$ & $61-63$ & 120 & 3.0 & 228.5 \\
\hline 22 & $2^{\circ} 17^{\prime} \mathrm{N}-97^{\circ} 27^{\prime} \mathrm{E}$ & $44-46$ & 120 & 3.0 & 221.0 \\
\hline 23 & $2^{\circ} 17^{\prime} \mathrm{N}-97^{\circ} 27^{\prime} \mathrm{E}$ & $53-60$ & 130 & 2.9 & 198.0 \\
\hline 24 & $2^{\circ} 15^{\prime} \mathrm{N}-97^{\circ} 26^{\prime} \mathrm{E}$ & $61-63$ & 130 & 3.0 & 225.8 \\
\hline 25 & $2^{\circ} 15^{\prime} \mathrm{N}-97^{\circ} 30^{\prime} \mathrm{E}$ & $32-45$ & 130 & 3.0 & 222.4 \\
\hline 26 & $2^{\circ} 11^{\prime} \mathrm{N}-97^{\circ} 30^{\prime} \mathrm{E}$ & $66-69$ & 120 & 3.1 & 177.0 \\
\hline 27 & $2^{\circ} 10^{\prime} N-97^{\circ} 29^{\prime} E$ & $27-36$ & 120 & 3.0 & 178.0 \\
\hline 28 & $2^{\circ} 11^{\prime} \mathrm{N}-97^{\circ} 31^{\prime} \mathrm{E}$ & $45-47$ & 120 & 2.8 & 208.8 \\
\hline 29 & $2^{\circ} 12^{\prime} \mathrm{N}-97^{\circ} 31^{\prime} \mathrm{E}$ & $56-59$ & 130 & 2.7 & 209.0 \\
\hline \multicolumn{2}{|l|}{ Average } & $38-69$ & 122.28 & 2.97 & 206.46 \\
\hline \multicolumn{2}{|c|}{ Standard deviation (SD) } & - & 7.41 & 0.10 & 18.03 \\
\hline \multicolumn{2}{|c|}{ Coefficient of variance (CV) } & - & $6 \%$ & $3 \%$ & $9 \%$ \\
\hline
\end{tabular}


Appendix Table 4. Catch of KM. Tunas Harapan in the fishing ground FG-4 in September 2007

\begin{tabular}{|c|c|c|c|c|c|}
\hline $\begin{array}{c}\text { No. } \\
\text { Setting }\end{array}$ & $\begin{array}{l}\text { Position } \\
\text { (Lat-Lon) }\end{array}$ & $\begin{array}{c}\text { Depth range } \\
(\mathrm{m})\end{array}$ & $\begin{array}{l}\text { Towing duration } \\
\text { (minute) }\end{array}$ & $\begin{array}{c}\text { Towing speed } \\
\text { (knot) }\end{array}$ & $\begin{array}{c}\text { Catch } \\
(\mathrm{kg})\end{array}$ \\
\hline 1 & $2^{\circ} 30^{\prime} \mathrm{N}-96^{\circ} 01^{\prime} \mathrm{E}$ & $45-48$ & 110 & 2.9 & 183.5 \\
\hline 2 & $2^{\circ} 25^{\prime} N-96^{\circ} 02^{\prime} E$ & $55-59$ & 100 & 3.0 & 282.8 \\
\hline 3 & $2^{\circ} 24^{\prime} E-96^{\circ} 01^{\prime} \mathrm{N}$ & $29-37$ & 120 & 3.0 & 210.0 \\
\hline 4 & $2^{\circ} 30^{\prime} \mathrm{N}-96^{\circ} 03^{\prime} \mathrm{E}$ & $41-62$ & 130 & 3.0 & 371.5 \\
\hline 5 & $2^{\circ} 29^{\prime} \mathrm{N}-96^{\circ} 04^{\prime} \mathrm{E}$ & $43-48$ & 110 & 3.0 & 287.9 \\
\hline 6 & $2^{\circ} 27^{\prime} N-96^{\circ} 01^{\prime} E$ & $36-44$ & 115 & 2.9 & 151.7 \\
\hline 7 & $2^{\circ} 27^{\prime} \mathrm{N}-96^{\circ} 02^{\prime} \mathrm{E}$ & $51-53$ & 125 & 2.8 & 181.4 \\
\hline 8 & $2^{\circ} 30^{\prime} N-96^{\circ} 02^{\prime} E$ & $66-68$ & 110 & 3.0 & 195.0 \\
\hline 9 & $2^{\circ} 31^{\prime} \mathrm{N}-96^{\circ} 01^{\prime} \mathrm{E}$ & $42-47$ & 120 & 2.9 & 221.0 \\
\hline 10 & $2^{\circ} 32^{\prime} \mathrm{N}-96^{\circ} 01^{\prime} \mathrm{E}$ & $38-41$ & 130 & 2.9 & 204.4 \\
\hline 11 & $2^{\circ} 33^{\prime} \mathrm{N}-96^{\circ} 01^{\prime} \mathrm{E}$ & $51-54$ & 120 & 3.0 & 367.8 \\
\hline 12 & $2^{\circ} 30^{\prime} N-96^{\circ} 01^{\prime} E$ & $62-67$ & 110 & 3.1 & 243.8 \\
\hline 13 & $2^{\circ} 31^{\prime} \mathrm{N}-96^{\circ} 01^{\prime} \mathrm{E}$ & $39-44$ & 130 & 2.9 & 200.6 \\
\hline 14 & $2^{\circ} 30^{\prime} \mathrm{N}-96^{\circ} 00^{\prime} \mathrm{E}$ & $30-33$ & 110 & 3.0 & 217.6 \\
\hline 15 & $2^{\circ} 33^{\prime} \mathrm{N}-96^{\circ} 01^{\prime} \mathrm{E}$ & $32-45$ & 125 & 2.9 & 226.3 \\
\hline 16 & $2^{\circ} 28^{\prime} \mathrm{N}-96^{\circ} 09^{\prime} \mathrm{E}$ & $55-57$ & 120 & 2.9 & 251.8 \\
\hline 17 & $2^{\circ} 27^{\prime} \mathrm{N}-96^{\circ} 04^{\prime} \mathrm{E}$ & $67-71$ & 110 & 3.0 & 223.0 \\
\hline 18 & $2^{\circ} 28^{\prime} N-96^{\circ} 09^{\prime} E$ & $41-62$ & 120 & 3.0 & 258.5 \\
\hline 19 & $2^{\circ} 29^{\prime} \mathrm{N}-96^{\circ} 07^{\prime} \mathrm{E}$ & $43-48$ & 120 & 3.0 & 199.0 \\
\hline 20 & $3^{\circ} 34^{\prime} \mathrm{N}-96^{\circ} 50^{\prime} \mathrm{E}$ & $36-44$ & 120 & 2.9 & 226.5 \\
\hline 21 & $2^{\circ} 26^{\prime} \mathrm{N}-96^{\circ} 10^{\prime} \mathrm{E}$ & $51-53$ & 115 & 3.0 & 291.5 \\
\hline 22 & $2^{\circ} 28^{\prime} \mathrm{N}-96^{\circ} 08^{\prime} \mathrm{E}$ & $44-46$ & 120 & 3.0 & 273.0 \\
\hline 23 & $2^{\circ} 26^{\prime} \mathrm{N}-96^{\circ} 09^{\prime} \mathrm{E}$ & $53-60$ & 120 & 2.9 & 214.8 \\
\hline 24 & $2^{\circ} 29^{\prime} \mathrm{N}-96^{\circ} 08^{\prime} \mathrm{E}$ & $61-63$ & 110 & 3.0 & 242.1 \\
\hline 25 & $2^{0} 30^{\prime} \mathrm{N}-96^{\circ} 05^{\prime} \mathrm{E}$ & $32-45$ & 110 & 2.9 & 283.2 \\
\hline 26 & $2^{\circ} 21^{\prime} \mathrm{N}-96^{\circ} 06^{\prime} \mathrm{E}$ & $54-56$ & 120 & 2.3 & 241.3 \\
\hline Average & & $32-71$ & 117.31 & 2.93 & 240.38 \\
\hline \multicolumn{2}{|c|}{ Standard deviation (SD) } & - & 7.51 & 0.14 & 52.10 \\
\hline \multicolumn{2}{|c|}{ Coefficient of variance (CV) } & - & $6 \%$ & $5 \%$ & $22 \%$ \\
\hline
\end{tabular}


Appendix Table 5. Catch of KM. Istana Samudera Indonesia in the fishing ground FG-3 in September 2007

\begin{tabular}{|c|c|c|c|c|c|}
\hline $\begin{array}{c}\text { No. } \\
\text { Setting }\end{array}$ & $\begin{array}{l}\text { Position } \\
\text { (Lat-Lon) }\end{array}$ & $\begin{array}{l}\text { Depth range } \\
(\mathrm{m})\end{array}$ & $\begin{array}{c}\text { Towing duration } \\
\text { (minute) }\end{array}$ & $\begin{array}{c}\text { Towing speed } \\
\text { (knot) }\end{array}$ & $\begin{array}{c}\text { Catch } \\
(\mathrm{kg})\end{array}$ \\
\hline 1 & $3^{\circ} 41^{\prime} \mathrm{N}-96^{\circ} 50^{\prime} \mathrm{E}$ & $41-53$ & 100 & 3.1 & 470.0 \\
\hline 2 & $3^{\circ} 44^{\prime} \mathrm{N}-96^{\circ} 45^{\prime} \mathrm{E}$ & $50-57$ & 110 & 3.0 & 244.2 \\
\hline 3 & $3^{\circ} 32^{\prime} \mathrm{E}-96^{\circ} 44^{\prime} \mathrm{N}$ & $71-75$ & 125 & 3.2 & 264.9 \\
\hline 4 & $3^{\circ} 38^{\prime} \mathrm{N}-96^{\circ} 46^{\prime} \mathrm{E}$ & $67-89$ & 120 & 3.2 & 278.7 \\
\hline 5 & $3^{\circ} 32^{\prime} \mathrm{N}-96^{\circ} 50^{\prime} \mathrm{E}$ & $80-88$ & 110 & 3.0 & 371.4 \\
\hline 6 & $3^{\circ} 28^{\prime} \mathrm{N}-96^{\circ} 36^{\prime} \mathrm{E}$ & $37-44$ & 120 & 3.0 & 296.0 \\
\hline 7 & $3^{\circ} 25^{\prime} \mathrm{N}-96^{\circ} 53^{\prime} \mathrm{E}$ & $87-91$ & 120 & 2.9 & 292.6 \\
\hline 8 & $3^{\circ} 30^{\prime} \mathrm{N}-96^{\circ} 58^{\prime} \mathrm{E}$ & $45-48$ & 120 & 3.1 & 302.0 \\
\hline 9 & $3^{\circ} 30^{\prime} \mathrm{N}-96^{\circ} 58^{\prime} \mathrm{E}$ & $57-63$ & 110 & 2.7 & 394.0 \\
\hline 10 & $3^{\circ} 27^{\prime} \mathrm{N}-97^{\circ} 01^{\prime} \mathrm{E}$ & $66-74$ & 130 & 3.0 & 200.4 \\
\hline 11 & $3^{\circ} 31^{\prime} \mathrm{N}-96^{\circ} 55^{\prime} \mathrm{E}$ & $71-83$ & 120 & 3.0 & 367.4 \\
\hline 12 & $3^{\circ} 40^{\prime} \mathrm{N}-96^{\circ} 53^{\prime} \mathrm{E}$ & $53-61$ & 110 & 3.3 & 226.0 \\
\hline 13 & $3^{\circ} 32^{\prime} \mathrm{N}-96^{\circ} 50^{\prime} \mathrm{E}$ & $71-73$ & 120 & 3.0 & 268.4 \\
\hline 14 & $3^{\circ} 34^{\prime} \mathrm{N}-96^{\circ} 52^{\prime} \mathrm{E}$ & $67-72$ & 125 & 3.1 & 273.5 \\
\hline 15 & $3^{\circ} 33^{\prime} \mathrm{N}-96^{\circ} 50^{\prime} \mathrm{E}$ & $36-47$ & 120 & 3.0 & 202.9 \\
\hline 16 & $3^{\circ} 34^{\prime} \mathrm{N}-96^{\circ} 49^{\prime} \mathrm{E}$ & $51-59$ & 100 & 3.0 & 328.0 \\
\hline 17 & $3^{\circ} 31^{\prime} \mathrm{N}-96^{\circ} 50^{\prime} \mathrm{E}$ & $84-87$ & 120 & 3.1 & 335.3 \\
\hline 18 & $3^{\circ} 32^{\prime} \mathrm{N}-96^{\circ} 49^{\prime} \mathrm{E}$ & $71-76$ & 125 & 3.0 & 377.5 \\
\hline 19 & $3^{\circ} 32^{\prime} \mathrm{N}-96^{\circ} 49^{\prime} \mathrm{E}$ & $80-93$ & 120 & 3.0 & 311.6 \\
\hline 20 & $3^{\circ} 34^{\prime} \mathrm{N}-96^{\circ} 50^{\prime} \mathrm{E}$ & $77-82$ & 130 & 3.0 & 219.5 \\
\hline 21 & $3^{\circ} 35^{\prime} \mathrm{N}-96^{\circ} 51^{\prime} \mathrm{E}$ & $53-77$ & 130 & 2.9 & 301.3 \\
\hline 22 & $3^{\circ} 33^{\prime} N-96^{\circ} 52^{\prime} E$ & $41-62$ & 120 & 3.0 & 299.1 \\
\hline \multicolumn{2}{|l|}{ Average } & $36-91$ & 118.41 & 3.03 & 301.12 \\
\hline \multicolumn{2}{|c|}{ Standard deviation (SD) } & - & 8.51 & 0.12 & 66.69 \\
\hline \multicolumn{2}{|c|}{ Coefficient of variance (CV) } & - & $7 \%$ & $4 \%$ & $22 \%$ \\
\hline
\end{tabular}

